(2) Open Access Full Text Article

\title{
Integrating medical simulation programs into the Turkish undergraduate medical curriculum
}

This article was published in the following Dove Press journal:

Advances in Medical Education and Practice

14 January 2016

Number of times this article has been viewed

\section{Dilek Kitapçıoğlu \\ Mehmet Emin Aksoy}

Medical Education Department, Faculty of Medicine, Acıbadem University, CASE - Center of

Advanced Simulation and Education, Istanbul, Turkey
Correspondence: Dilek Kitapçıŏlu Acıbadem University, CASE - Center of Advanced Simulation and Education, Kayisdagi cad. No :32 34752 Istanbul,Turkey

Email dilekitapci@gmail.com

\section{Dear editor}

The letter by Ah-kee and Khan ${ }^{1}$ arguing that a mandatory year for studying leadership management within an already overcrowded undergraduate curriculum is not realistic and feasible drew our attention. We strongly support this idea because of the difficulties we met during integration of simulation programs into the undergraduate curriculum in Turkey.

The Turkish Higher Education Council plans the curriculum for medical faculties in Turkey. Till date, actually, medical simulation has still not been implemented into the national curricula. Medical simulation trainings are essential for improving both basic and advanced skills in a safe environment and their competency for crisis resource management, which is very important for leadership, communication, and teamwork in health care education. ${ }^{2}$ For this purpose, our faculty, which is part of a foundation university, decided to integrate medical simulation into our undergraduate program. Center of Advanced Simulation and Education (CASE) has been founded by our university in 2013 and is the first large-scale interdisciplinary medical simulation center in our country. CASE offers different types of simulation-based experiential learning via standardized patients, virtual reality task trainers, high-fidelity manikin-based simulators, wet lab sessions for robotic and laparoscopic surgery, and cadaver-based training sessions. Between 2013 and 2015, the total number of trainees who took part in the training events at our center was 23,450. As periodic inspections are performed by representatives of Turkish Higher Education Council in terms of compatibility of undergraduate medical simulation programs to minimum competency requirements of the Turkish Ministry of Health, simulation sessions have to be well integrated into the curricula to fulfill these criteria.

In our faculty, undergraduate training programs have been organized by the Education and Research Committee consisting of medical faculty educational directors, nursing faculty educational directors, paramedic trainers, and anesthesiology technicians' educational directors. The committee develops department-specific curricula and evaluates their programs. The committee has selected specific educators from each department who are responsible for simulation trainings. Orientation programs and training the trainer courses are organized by the core team of our simulation center. However, most of faculty staff had negative attitude against this kind of changes and resisted to adapt to additional practice hours and content related with simulation sessions. Overcrowded undergraduate curriculum caused another problem 
in organizing time slots. Because of this resistance and limitations, only $40 \%$ integration could be achieved into the existing curriculum in the first year and all sessions had to be given by simulation center's core staff. The first issue was negative attitude toward simulation. To overcome this, we organized simulation sessions for pilot groups from each department such as advanced life support courses for nursing students, boot camp courses for intern medical students, and interdisciplinary crisis resource management trainings for the academic staff to show how this type of education can be implemented into the existing program. The second issue was organizing time slots. To solve this problem, we used free time of the students with their approval. We assessed the performances of the trainees and determined positive effects in their clinical performances. Interdisciplinary trainings and their impact on clinical performances of students drew attention of academic staff, who afterward wanted to be part of this process. After evaluating the programs with feedbacks of trainees and educators, the governing board of CASE and Education and Research Committee concluded that more simulation-based trainings should be embedded into the curricula. The Board of Trustees of our university evaluated the effectiveness of simulation programs and decided to give more financial support.

In the third year of the implementation process, all departments are actively using CASE and the time slots are well organized according to the existing curricula.
In conclusion, implementing different teaching initiatives into the undergraduate curriculum is a difficult process that has to be well organized and needs collaboration of both academic staff and administration. Defining target groups and their needs, learning how to optimize, refine, and adapt to existing programs could be the starting point of program implementation. Initiating integration with pilot groups and controlling each step by feedbacks could be the second step. For integration, collaboration of students is also required to overcome barriers. Their positive feedbacks and ambition to act in simulation environment helped us to overcome this complex process. However, we still have difficulties in implementing medical simulation into the curricula of Turkish universities, as the impact of simulation on clinical performances has still not been accepted in our country and there is no national curriculum embedded with simulation programs. Therefore, each university is trying to solve this problem by its own resources.

\section{Disclosure}

The authors report no conflicts of interest in this communication.

\section{References}

1. Ah-kee EY, Khan AA. Incorporating medical leadership and management into the UK undergraduate medical curriculum. Adv Med Educ Pract. 2015;6:507-508.

2. Qayumi K, Pachev G, Zhang B, et al. Status of simulation in health care education: an international survey. Adv Med Educ Pract. 2014;5:457-467.

Dove Medical Press encourages responsible, free and frank academic debate. The content of the Advances in Medical Education and Practice 'letters to the editor' section does not necessarily represent the views of Dove Medical Press, its officers, agents, employees, related entities or the Advances in Medical Education and Practice editors. While all reasonable steps have been taken to confirm the content of each letter, Dove Medical Press accepts no liability in respect of the content of any letter, nor is it responsible for the content and accuracy of any letter to the editor.

Advances in Medical Education and Practice

Dovepress

\section{Publish your work in this journal}

Advances in Medical Education and Practice is an international, peerreviewed, open access journal that aims to present and publish research on Medical Education covering medical, dental, nursing and allied health care professional education. The journal covers undergraduate education, postgraduate training and continuing medical education including emerging trends and innovative models linking education, research, and health care services. The manuscript management system is completely online and includes a very quick and fair peer-review system. Visit http://www.dovepress.com/testimonials.php to read real quotes from published authors. 